\title{
Islamic economics versus market economics: The concept of taxations
}

\author{
Farhang Mossavar-Rahmani, Hamid Maleki \\ (School of Business and Management, National University, San Diego CA-18047, USA)
}

\begin{abstract}
Taxation plays a major role in both market economics and Islamic economics. The difference is that in market economics, the tax system has evolved throughout the centuries in order to address the constant change in market-based societies. In Islamic economics, however, the tax system bases on the writings of the Qur'an and the principles of shariah. As a result, it did not flourish as the needs of Islamic society changed. Therefore, governments in Islamic countries that seek to follow Islamic law are facing major economic challenges. Recently, some Islamic scholars have asserted that Islamic governments can go beyond the explicit instructions of the Qur'an and impose taxes as needed. They justify their arguments based on the interpretation of Qur'anic verses. This paper briefly compares both rationality and the methods of taxation in both market economics and Islamic economics, and further elaborates on the shortcomings of the original Islamic tax laws.
\end{abstract}

Key words: tax; Islamic economics; market economics

\section{Introduction}

Tax plays a major role in both market economics and Islamic economics. However, each of them have different methods of taxation. In market economics, the tax system has evolved throughout the centuries to address the needs of constantly changing market-based societies. In Islamic economics, the tax system has been based on the writing of Qur'an and the principles of shariah. Since the wording in the Qur'an and Shariah has not changed, the tax system has not evolved too, even though the needs in these countries have changed. In this paper, the authors review and compare both concepts and explain some of the challenges being faced by Islamic countries that wish to adopt Islamic laws.

\section{The historic approach}

\subsection{Pre-industrial revolution area}

At the beginning, one of the main characteristics of human beings has been their tendency to live collectively, in a society, and the beginning the advantages of gathering in form of social entities, were mostly self-protection, whether protection againsts external factors, such as rival societies, or internal factors, such as justice among members in the same group. In all cases, it required organization, hence expenditures.

Soon after, the concept of "public good" was added to the concept of defense as part of the requirements of a social system. Public goods being goods that benefit the collective masses rather than the individual; They could not be financed or purchased individually by the members of the society, hence it is necessary for collective

Farhang Mossavar-Rahmani, D.B.A, professor of finance, School of Business and Management, National University; research field: finance and economics.

Hamid Maleki, M.S., core adjunct faculty of economic, School of Business and Management, National University; research field: economics. 
management. Two good examples of this are building roads and maintaining security in the cities. In order to achieve that, societies ought to create a political system that requires an administration for function. Such a system had to be financed through taxation by the individual members in that social system. Since the renaissance, these social structures were reinforced by the advent of large cities, which increased the cost and led to higher taxes.

Although taxation becomes more and more varied and organized, in essence, it was very simple. Taxes were collected mostly from the agricultural sector in a pyramidal pattern. Serfs (farm laborers) would pay the seigneurs (landowners) their dues after picking up the crop. Seigneurs would in turn pay the potentate (Kings or their vassal) their share. Other less important types of taxes became customary, such as taxes on the entrance to a city by merchants (the ancestor to Islamic tariffs), or to market (the ancestors to Islamic sales tax). Others were more sophisticated, such as the taxes on salt imposed by everyone with their meals. In 1947, the Indian liberator Mahatma Gandhi, as a symbolic gesture, asked his fellow countrymen to refrain from consuming salt, because the British taxed it. And a massive march was organized toward the ocean to produce untaxed salt. Other unusual taxes that were collected included taxes from homeowners (the ancestor of our property or wealth tax) or taxes on renters of homes along important streets, which based on the number of windows facing the street. All these taxes had one common denominator- the ease of collecting them.

The situation was relatively the same during the time of Prophet Mohammad, except that the society in which the Prophet was living was smaller and less sophisticated (a tribal based society), and as a result, the need for systematic taxation was not necessary.

\subsection{Post-industrial revolution area}

The industrial revolution transformed society from one where most individuals struggled to survive by planting crops for their own use, only supplying the market marginally, into a society of consumption. The use of external energy, with the help of machinery, permitted the results that increased productivity transferred to the worker operating machine, and then increased the purchasing power of the individual. It also redistributed income in a more homogenous manner, allowing more people to buy more goods.

Although the transition has not been spontaneous, and took close to a century, the industrial revolution has been a turning point in the context of taxation. It has drastically changed the concept, objectives, means and functions of taxation. With the gradual apparition of modern public goods, first due to the exponential growth of the cities and the need to establish a social harmony in order to allow a continuous economic growth, furthermore, due to the need for an infrastructure to link markets nationally and globally, modern taxation has played a crucial role in creating Islamic modern societies.

The main difficulty was to differentiate public goods and all other goods, or private goods. It is just recently (in the second half of the twentieth century) that economists managed to define the characteristics of public goods. Public good has two components: social cost or benefit and private cost or benefit. The private cost or benefit, like any other goods is reflected by its market price. But on the other hand, the market does not reflect the social cost or benefit; Hence, a public good is priced by its inherent social values. These hidden costs or benefits are called externalities and they can be negative or positive. Pollution has negative externalities that are not reflected by the market price of water or air, because both of these products are too abundant in nature to have any economic value (the price of a good depends on its scarcity in the market). On the other hand, the value of education is also not reflected by its market price either, because it not only benefits the recipient but society overall. An example of this would be that when a scientist discovers a vaccine, it benefits everyone, not just the scientist. By defining the characteristics of a public good in this manner, it has been easier to differentiate public and private goods, but still 
remains the problem as how to evaluate the monetary value of the social costs or benefits. In market economy, this has been delegated to the political system to evaluate (in democracies by the ballot directly or indirectly).

Furthermore, under this framework, the concept of defense and protection of society, its organization and maintenance of a political system could easily be explained and evaluated with the help of the "social cost-benefit" approach. The only means by which the political system could be maintained is the collective monetary participation for all the members in that social system. The collective monetary participation is done through individual taxation.

An important problem that society faces with collective monetary participation is the rules by which that participation could take place. Should the taxes be equal for every individual in a society or should it be proportional to the income or wealth of the participants? Here again the economists have found a solution. A unit of local currency will buy the same amount of a particular good, but the same unit of currency is more valuable for a poor person than a rich one. Therefore, by paying the same amount, the poor person will give up more than the rich one. The worth of one hundred dollars is much more for a starving student than a millionaire. Economists call this the opportunity value of money. The opportunity value of money is different from one individual to another; So, the value of taxes should be proportional to their income or wealth, it is not just to be fair, but also affordable by every member in that social entity, hence allowing collective participation. Although it is very rational, the concept of proportionality is not very easy to implement.

Another problem is who should collect taxes and what the procedure should be by which social goods can be realized. Although most taxes today are collected by the governments to realize the social projects, some voluntary taxes are also collected by religious or other entities for their own social objectives. Religious entities always play important roles in collecting taxes and redistributing income due to their continuity and ease of enforcement because of the participants' beliefs.

\section{Present tax structure in market economics}

One cannot study the subject of taxation without understanding the roles and functions of government in the society. In market economy, the role of government can best be described by what it is supposed to do, which is mainly to provide goods and services (such as education, national defense, public safety, etc.), distributing income, regulating business practices and international trade.

If government is to do its job, it needs resources. In market economy, the main resource available to the government is revenue coming from taxation (borrowing is another source of financing which ultimately should be paid off by taxation). Therefore, in market economy, taxation has three main objectives:

(1) To support government expenditures;

(2) To redistribute income;

(3) To implement macroeconomic policies through fiscal policy.

The following are brief descriptions of each one.

\subsection{Financing government expenditure}

The oldest and the most obvious reason for collecting taxes is to finance government expenditures. On one hand, these expenditures maintain the political system that enforces the wishes and wills of society; On the other hand, it realizes projects that benefit society collectively which no individual or organization is willing or capable to support alone (public goods). Furthermore, these expenditures are required to protect societies externally 
against outsiders, and internally via the social order built by implementing and enforcing rules and regulations in every domain where the public has delegated them the power to do so.

\subsection{Redistributing of income}

The purpose of redistributing income becomes a necessity in order to allow a homogenous economic growth. In this framework, some of the most important forms of income redistribution are unemployment compensation and the social security system (implemented in France in 1910 and in United States in 1918). The purpose of these taxes and expenditures (a negative tax) is to redistribute a portion of the purchasing power from the working population to the non-working population, therefore it increases the overall purchasing power of the society in order to expand the economy.

\subsection{Macroeconomic policy}

Soon after, taxes and government expenditures were used to correct the economic fluctuations when they would get out of control. John Maynard Keynes invented this new function of taxes during the global economic crisis in the 1930s, which was called Fiscal Policy. In this context, taxes are used to boost up the economy through reducing taxes and increasing government expenditures (negative taxation) by creating a deficit in the budget. In turn, this deficit would increase, through a more than proportionate amount (the multiplier effect), the population's income and then its power of purchase. On the other hand, whenever the economy would overheat, such as inflation, the government would increase taxes and reduce government spending, and generate a budget surplus at last. Contrarily, this surplus would shrink the level of income more than proportionately and reduce the populations' power of purchase, as a result, demand slows down and inflation reduces. These types of macroeconomic policy tools have shortcomings and should only be used for long-term adjustments.

\section{Tax in Islamic economics}

Taxes and the tax system under Islamic jurisprudence are somewhat complicated and to some degree a matter of subjective interpretation of the scholars who studied them. It becomes even more challenging when one wishes to review them under different Islamic schools (i.e. the Shiite sect and/or the four Sunni sects). Since the purpose of this section is a brief review of tax and tax systems in Islamic economics, the authors leave the detailed discussion under each Islamic school for another day. However, before we define the concept of tax in Islam, it will be helpful to briefly review the principals of Islamic economics and how did they differ from those of market economics.

\subsection{The differences between Islamic economics and market economics}

Capitalism is an economic doctrine based on the idea of private ownership of the means of production and distribution. Modern western economics are based on market transactions between people who voluntarily decide whether or not to engage in them. They have the right to buy and sell what they want, to accept and refuse offered work, and to move no matter where and when they want.

Adam Smith, the father of modern economics, argued that as long as people are able to freely cooperate with each other on a voluntary basis, all parties will benefit. Self- interest is a key factor in guiding individuals in this voluntary exchange of goods and services. The price system, in turn, is the best mechanism to achieve this cooperation.

The distribution of income in market economics is determined by the ownership of the factors of production (labor, capital, land and entrepreneurship). Friedman (1979, p.20) described the distribution of income as follows: 
The income each person gets through the market is determined, as we have seen, by the difference between his receipts from the sale of goods and services and the costs he incurs in producing those goods and services. The receipts consist predominantly of direct payments for the productive resources we own-payments for labor or the use of land or buildings or other capital.

According to Gerald Cavanagh (1984), the possibility of unlimited profits is at the heart of the free market's strength. This draws a person into greater activity and creativity, and most importantly, it quickly rewards those efforts. Furthermore, the rewards are tangible and measurable. As Cavanagh (1984, p.43) argued, "by these standards there is little doubt as to who is a success".

But this success comes at a very high price. According to Cavanagh $(1984, \mathrm{p} .65)$ : This new model for economic activity also includes the system's greatest weakness. It insulates a person from the older and clearly perceived obligations to friends, family, fellow citizens and the larger community, and replaces them with an easily broken contract whose purpose is to obtain individual profit. Hence, individuals can much more readily come to feel that they are alone, that they are isolated, and that they are easily replaceable.

Islamic economics is different. Islam is a complete way of life. It not only concerned with the spiritual upliftment of human beings, but also equally concerned about their material and physical well-being. In Islam, God is the creator and owner of wealth and property is a trust; It is entrusted to human beings to use, not only to ensure living and enjoyment, but also to bear witness to God's benevolence by exalting his message and his spreading good: God is the creator and owner of wealth and people are the vice-regents of God; However, people can pursue and use wealth in the form of a trusteeship from God (Quran).

The economic doctrine of Islam is closely related to the Islamic concept of life and is part of it. This concept is based on a network of interrelated concepts of God, humanity, man's relationship to God, man's position in the universe and the relationship of man to his fellow men (Abdul-Rauf, 1979).

Islamic economics, therefore, deals with a wide range of issues, encompass social and economic behavior of all individuals. In other words, Islamic economics presents an Islamic viewpoint on the human economic situation, having social justice as its cornerstone. Its root, according to Akram Khan (1991, p.248), “goes deep into Islam's vision of human nature".

There are other but similar definitions of Islamic economics. For example, Zaman (1984, pp.51-53) stated that: Islamic economics is the knowledge and application of injunctions and rules of the Shari'ha (Islamic jurisprudence) that prevent injustice in the acquisition and disposal of material resources in order to provide satisfaction to human beings and enable them to perform their obligations to Allah (God) and society.

"Islam is a way of life”, asserted Reilly and Zanganeh (1990, p.28), "This is important because it dismisses separation of ethics, economics, politics, sociology, religion, etc. All aspects of life are interrelated. One cannot separate a company's president or a country's president from the environment that he/she has been fostered in and is living in".

\subsection{The concept and role of tax in Islamic economics}

Based on the principals of Islamic economics and the fact that God is the ultimate owner of everything, Islam has a completely different approach toward the taxations versus market economics. In Islamic economics, taxes must be paid according to the will of God manifested in the principles laid down by Him in the Qur'an. At this base, a tax must be just and only those who are qualified should pay taxes.

In general, Islamic jurisprudence recognizes individuals as taxpaying units. As such, households, corporations and other entities are not taxed (Jalili, 2006). Since the tax payment is merely based on individual 
willingness and not imposed by the government, the tax system in Islamic countries has not fully developed and traditional taxation is not very effective in generating enough revenue to support necessary government expenditures with its goals.

However, on an individual level, economic equality is pursued through the moral and ethical teachings of charity, and in Arabic, this is known as sadaqah and infaq. There are many verses in the Quran which command the Muslims to help others voluntarily. There are more verses dealing with voluntary charity than the obligatory dues. Everyone is morally obliged to help others according to his or her own means and resources. Even though this by itself has been a major factor in reducing poverty in many Muslim countries (Sala-i-Martin \& Artadi, 2003). Nevertheless, this process by nature cannot be clear and precise. In addition, the tax calculations are a matter of interpretation and personal judgment. According to Jalili (2006, p.18): Not surprisingly, throughout the history of Islam, various interpretation and differences of opinions have emerged on details and mechanism of taxation. This phenomenon, in itself, is not peculiar to Islam. What is rather unique is that writings on Islamic taxation in general and zakat and Khums in particular, are largely reactive in nature. The literature is predominantly detailed case-by case treatment of specific questions and circumstances that has evolved into legal precedent.

\subsection{Methods of taxations}

In Islam, two tax structures have been adopted, one for Muslims and another for non-Muslims. In each case, there are different types of taxes and each is designed to achieve certain goals. For example, since the distribution of income cannot be based only upon the participation of factors of production in economic activities, income is supposed to be distributed through "zakat" (a wealth tax), which is an obligation on Muslims to pay 2.5\% of their wealth to specify categories in society, when their annual wealth exceed the minimum level (nisab). For Non-Muslims, there is a tax code called Jizyah, which is a tax on non-Muslim citizens who meet certain criteria and are exempt from military services yet the government guarantees his/her security.

Shiea, recognizing that zakat alone may not be enough, also required another form of distribution of income called Khums. Khums is a $20 \%$ tax on all kinds of property where zakat is not levied and it is divided into two parts. One part is Sehme Sadaat, and should be given to a Sayyid who is poor, or an orphan, or one who has become stranded without money during his journey. The second part is Sehme Imam (A.S.), and during the present time it should be given to a Mujtahid, who fulfils all conditions, or can be spent for such purposes as allowed by that Mujtahid. As an obligatory precaution, that Mujtahid must be Aalam, and well versed in public affairs.

\section{The different modes of collecting taxes}

In market economics, there are a variety of different types of taxes, yet all can be grouped into three different modes for purposes of collection. These are taxes on wealth, taxes on transactions and taxes on income.

\subsection{Taxes on wealth}

Taxes on wealth are the easiest way of collecting taxes, especially when it is imposed on real estate. If this type of tax is perceived directly from the wealth itself it will, with time, annihilate the wealth. Because payment from wealth can only be done after the goods' selling, it becomes a transactional tax. Therefore, taxes on wealth are usually paid from the wealth owner's income. This type of tax is easily collected.

As explained before, in Islamic economy, taxes on wealth are called zakats (there are different types of zakats 
like a zakat of land, a zakat on livestock and a zakat on gold, silver etc, but they all can be classified as a zakat on wealth). The method of calculation of a zakat is somewhat complicated. Firstly, a zakat should be paid on voluntary basis. Secondly, it is mostly based on the individual judgment, and for that reason it is arbitrary. Thirdly, someone see it as an act of purification and someone see it as an act of charity, while others see it as a duty. There are some others like Zayas (1961) who believe that zakat is not a tax in any sense of the term. Therefore, the manner in which it is calculated (i.e. the level of accuracy) is heavily influenced by how an individual perceives its purpose. Fourthly, it is calculated based on the individual's wealth (assets that generate economic return) and his/her level of consumption. Each one of these can be decided arbitrarily and therefore, there is no way to determine the base of its calculation. Fifthly, it only applies to the individual but not to a business. In general, individuals who earned more than his/her consumption must pay a zakat.

\subsection{Taxes on transaction}

Taxes on transactions are more difficult to collect, because if both parties of the transaction agree to avoid the payment of taxes, then they would not pay the tax (in an extreme case, it could become barter). Therefore, governments have to find indirect ways to collect them. Up to modern times, transaction taxes were collected at the gates of the cities. When merchants enter a city or a port, taxes were collected in order to let them have access to the local market. A good example is the free cities in Europe after the post renaissance period, such as Venice or the Hansa stadt (Hamburg, Hanover \& Stuttgart). In modern times, the bookkeeping of merchants and register machines have largely helped in avoiding infractions. This type of tax, although easily collected, is unfair because the poors are at a disadvantage that they must pay the same amount of tax for the same product as the rich, therefore they bear a heavier proportionate cost to their income (the opportunity cost of money).

In Islamic economics there is no tax on transactions.

\subsection{Taxes on income}

Taxes on Income are the most difficult taxes to collect. Some economists call the income tax a "voluntary tax". With the income tax, the authorities do not define the amount of the tax and they only set the rules under which the amount should be calculated. It is left up to the taxpayer to calculate and define under these rules the amount of taxes due. Furthermore, for the cost of reviewing and controlling individually, every taxpayer's submission is too costly and prohibitive. Conversely, it is also the fairest type of tax. Its fairness is due to its main characteristic, which is the rule of proportionality. Taxes on income are always proportional to the original income, contrary to a wealth or transactional tax, both of which are based on the value of a good. Therefore while it is the fairest tax, collecting an income tax is very difficult and requires a very high level of social morality, integrity and discipline by the participant.

In Islamic economics, there is no tax on income. However, income for each year is added to the existing level of wealth and may be taxed through a zakat if the balance shows a net increase in wealth.

\subsection{Challenges facing Islamic government wish to implement Islamic taxation}

Applying the Islamic taxation system as described in Qur'an or Shariah (system of divine law), while has its own advantages (mainly it leaves the average person with more disposable income, which has a major impact on economic activities), it cannot address the practical financial needs of Islamic countries. This is why, with the exception of Saudi Arabia, Muslim countries use a more market-based approach toward taxation. As Table 1 shows, a very small percentage of government revenue is generated from zakat.

Some of the main obstacles in collecting zakats are: determining a base for a zakat, a lack of legal compulsion, in efficiency of the zakat collection and lack of trust of the contributors of zakat in collecting agencies. 
Islamic economics versus market economics: The concept of taxations

Table 1 Zakat revenue as percentage of GDP in some of the Islamic countries

\begin{tabular}{|c|c|c|c|c|}
\hline Country & $\begin{array}{l}\text { Government spending } \\
\text { as percentage of GDP }\end{array}$ & Tax system and rates & $\begin{array}{c}\text { Zakat revenue as } \\
\text { percentage of GDP }\end{array}$ & $\begin{array}{c}\text { Tax revenue as } \\
\text { percentage of GDP }\end{array}$ \\
\hline Azerbaijan & & $\begin{array}{c}\text { Income tax } 0-35 \% \\
\text { Corporation } 22 \%\end{array}$ & Less than $0.05 \%$ & \\
\hline Bangladesh & $13.9 \%$ & $\begin{array}{c}\text { Income tax } 25 \% \\
\text { Corporate tax } 45 \%\end{array}$ & $0.05 \%$ & $8.5 \%$ \\
\hline Egypt & $33.6 \%$ & $\begin{array}{c}\text { Income tax } 20 \% \\
\text { Corporate tax } 40.55 \%\end{array}$ & Less than $0.10 \%$ & $15.8 \%$ \\
\hline Indonesia & $20.0 \%$ & $\begin{array}{c}\text { Income tax 35\% } \\
\text { Corporate tax 30\% }\end{array}$ & Less than $0.30 \%$ & $11.0 \%$ \\
\hline Iran & $26.0 \%$ & $\begin{array}{c}\text { Income tax } 35 \% \\
\text { Corporate tax } 25 \%\end{array}$ & Less than $0.05 \%$ & $7.3 \%$ \\
\hline Morocco & $28.0 \%$ & $\begin{array}{c}\text { Income tax } 42 \% \\
\text { Corporate tax } 35 \%\end{array}$ & Less than $0.20 \%$ & $22.3 \%$ \\
\hline Pakistan & $17.6 \%$ & $\begin{array}{c}\text { Income tax } 25 \% \\
\text { Corporate tax 35\% }\end{array}$ & $0.25 \%$ & $10.6 \%$ \\
\hline Saudi Arabia & $29.8 \%$ & $\begin{array}{c}\text { Income tax } 0 \% \\
\text { Residents } 2.5 \% \text { zakat } \\
\text { Non-residents } 20 \% \\
\text { Corporate tax } 2.5 \% \\
\end{array}$ & Less than $0.15 \%$ & $5.3 \%$ \\
\hline Tunisia & $26.9 \%$ & $\begin{array}{c}\text { Income tax 35\% } \\
\text { Corporate tax 30\% }\end{array}$ & Less than $0.10 \%$ & $14.9 \%$ \\
\hline Turkey & $23.5 \%$ & $\begin{array}{c}\text { Income tax } 34 \% \\
\text { Corporate tax } 20 \%\end{array}$ & Less than $0.10 \%$ & $32.5 \%$ \\
\hline Unaided Kingdom & $40.0 \%$ & $\begin{array}{c}\text { Income tax } 40 \% \\
\text { Corporate tax } 28 \%\end{array}$ & Zero & $39.0 \%$ \\
\hline United Sates & $36.7 \%$ & $\begin{array}{c}\text { Income tax 35\% } \\
\text { Corporate tax 35\% }\end{array}$ & Zero & $28.2 \%$ \\
\hline
\end{tabular}

Data sources: 2009 Index of economic freedom and various Islamic banks reports.

Note: Generally tax to GDP ratio is around $40 \%$ in high income countries, $25 \%$ in middle income countries and $18 \%$ in low income countries.

Faced with such a dilemma recently, some Islamic scholars have begun to make a case for additional taxes by suggesting that instead of following the tax laws designed for market based countries; Islamic countries should develop their own tax system by going beyond the wording of Qur'an and focusing more on the underlying intention of the verses. Among these scholars, Askari, Iqbal and Mirakhor have suggested that if a zakat is not sufficient for government expenditures, then the government can impose an additional tax. They refer to the fact that the Qur'an clearly promotes justice and fairness in society, therefore, any action taken by an Islamic government that promotes justice should be acceptable. They further emphasize that since God is the ultimate owner of everything, ownership in Islam cannot be absolute. Thus the distribution of income and wealth must be just too, as indicated by the principles laid down in the Qur'an and manifested in the life of the Prophet (phup) (2009).

Jalili (2006) also has a similar argument. He argues that theoretically the functions and intentions of the Islamic tax system are rather clear. In addition, to raise funds for sustainning a functioning Islamic Sate, taxes are designed to facilitate the movement of society toward the achievement of Islamic goals and the establishment of a just society. This may be accomplished by such a tax system which aims at alleviating poverty, satisfying the people's needs and improving income distribution among members of a society.

Faruki (1972) used a different rational for justifying other forms of taxes. He suggests that while the five pillars of faith cannot be changed, some less formal varieties can be implemented, so long as they are in line with the goals of the Islamic doctrine. He states: As du'a and other varieties of less formal prayer than salat are 
Islamically permissible and indeed meritorious, so long as they conform to basic principles of salat, similarly other varieties of taxation are permissible and desirable, but only so long as they conform to the basic principles of original zakat.

In short, many Islamic scholars believe that, keeping in mind the role of Islamic governments, which should act based on the principles of Islamic laws and in the direction of creating just, fair and prosperous society for all Muslims, they can design a just tax system that allows them to raise taxes beyond what a zakat and other existing tax systems can generate.

\section{Conclusion}

While there are differences between market economics and Islamic economics, taxes play a major role in both of them. However, since the taxes in Islamic economics are based on the writings of the Qur'an, which cannot be changed or modified, the Islamic tax system, unlike market based one, has not been changed from the time of Prophet Mohammad. This lack of evolution of the Islamic tax system has created major challenges for the Islamic countries that seek to implement Islamic law and follow the principles of the Islamic economics. Historically, the total revenue generated through the zakat (see Table 1) in each Islamic country historically, has not been adequate enough to address the needs of the Islamic governments in financing their expenditures or supporting the redistribution of income.

Facing this dilemma, some Islamic scholars have recently been promoting the idea that, in order to address the issue of taxation in Islamic economics, one has to look at the ultimate function of the Islamic government, which is moving society toward prosperity and justice for all. Therefore, Islamic government can set up an additional tax system that aims at alleviating poverty, satisfying the people's basic needs and improving redistribution of income among the members of a society.

\section{References:}

Askari, Hossein, Iqbal, Zamir \& Mirakhor, Abbas. (2009). New issues in Islamic finance and economics: Progress and challenges. Singapore: John Viley \& Sons (Asia) Pte. Ltd, 266-267.

Abdul-Rauf, Muhammad. (1979). The Islamic doctrine of economics and contemporary economic thought. In: Michael Novak (Ed.), Capitalism and socialism: A theological inquiry. Washington, D.C.: American Enterprise Institute Sponsored.

Akram Khan, Muhammad. (1991). The future of Islamic economics. Futures, 23(3), 248-262.

Cavanagh, Gerald F.. (1984). American business values: A global perspective. New Jersey: Prentice Hall, Inc.

Friedman, Milton. (1979). Free to choose. New York: Harcourt Brace Jovanovich.

Hosseini, Hamid. (1988). Notions of private property in Islamic economics in contemporary Iran: A review of literature. International Journal of Social Economics, 15(9), 53.

Jalili, Ali Reza. (2006). A descriptive overview of Islamic taxation. The Journal of American Academy of Business, 8(2), 16-28.

Kemal A. Faruki. (1972). Islamic taxation and the philosophy. Islam and Social Justice, 7, 34-45.

Presley, John R. \& Session, John G.. (1994). Islamic economics: The emergence of a new paradigm. Economic Journal, 104(424), 584-596.

Reilly Beernard J \& Zangeneh, Hamid. (1990). The value-based Islamic economic system and other optimal economic systems: A critical comparative analysis. International Journal of Social Economics, 17(11), 30-32.

Siddiqi, Muhammad Nejatullah. (1991). Some economic aspect of mudarabah. Review of Islamic Economics, 1(2), 21-33.

Weiss, Dieter. (1989). The structure for a viable Islamic economy. The Muslim World, 79(1), 46-59.

Xavier Sala-i-Martin \& Elsa V. Artadi. (2003). Economic growth and investment in Arab world. Economics Working Paper No.683, 25.

Zaman, Hasanuz. (1984). Definition of Islamic economics. Journal of Research in Islamic Economics, 1(2), 85.

Zayas, Farishta. (1969). The functional role of zakat in the Islamic social economy. The Islamic Literature, 15(3), 5-10.

(Edited by Ruby and Chris) 